DOI: 10.46340/ephd.2020.6.2.11

Fedir Stryzhachuk, PhD in Theology

ORCID ID: https://orcid.org/0000-0002-3644-938213

National Pedagogical Dragomanov University, Ukraine

\title{
MISSIO DEI AND MISSION \\ OF THE CHRISTIAN CHURCH
}

\author{
Федір Стрижачук, кандидат богословських наук \\ Національний педагогічний університет імені М.П.Драгоманова, Україна
}

\section{MISSIO DEI I МICIЯ ХРИСТИЯНСЬКОÏ ЦЕРКВИ}

For most of the history of the Christian mission to the nations, the mission was considered as the work and task of the church. The article shows that the renaissance of Trinitarian theology in the 20th century allows us to comprehend the Christian mission in a new way: the mission is the work of the triune God. The mission is based on the Trinity and reflects the nature, will, and activity of the Father, the Son, and the Spirit. The missiological emphasis on Missio Dei calls for the unification of missiology and trinitarian theology into a single theological discourse. In the light of Missio Dei as the foundation of the mission, the Christian church is called and equipped by God to become a living instrument in God's mission and to become an active participant in it. The mission of the church is directly related to the soteriological work of Christ and the mission of the Spirit. The mission of the church is to continue the work of Christ for reconciliation, which is inclusive and covers the whole universe. The reconciliation is the exclusive work of Christ in union with the Father and the Spirit, but it is all-encompassing in scale. The purpose of the mission is to bring people and all creation into living communion with the Trinity and through Him with one another.

Keywords: Christian mission, missiology, doctrine of the Trinity, Missio Dei, church.

Вступ. До недавнього часу богослов'я місії не було помітною дисципліною серед богословських дисциплін, ще в меншій мірі богослов'я місії будувалося на фундаменті доктрини про Трійцю. Кінець колоніалізму та завершення доби спільного домінування християнської церкви та християнської держави (Corpus Christianum) зумовили значну дискусію про природу місії та ії функцію у житті церкви та богословському мисленні. Единбургська місіонерська конференція 1950 року стала вододілом у місіонерській активності та мисленні. Проте, іiі основним досягненням стало не посилення місіонерської активності і рефлексії над нею, а початок екуменічного руху. Сучасний місіонерський рух та богослов'я місії $є$ досить різноманітним. В останні десятиліття з проникненням тринітарного богослов'я у всі сфери християнського життя і служіння, сфера місіології не залишилася поза впливом тринітарної рефлексії ${ }^{1}$. У цьому дослідженні ми звернемо увагу на тринітарну основу місії та імплікації доктрини про Трійцю у розумінні природи та завдань місії.

Основа місії: Missio Dei. Термін Missio Dei почав використовуватися і став звичним у богословському дискурсі після місіонерської конференції у Веллінгені в 1952 році ${ }^{2}$. Після Веллінгенської конференції розуміння місії як Missio Dei прийняли практично всі християнські конфесії․ Проте, ідея місіонерства як дії Самого Бога була виражена на Брандербургській місіонерській конференції у 1932 році Карлом Бартом. Та сама думка була переконливо сформульована в монографії Карла Хартенштейна Місіонерство як богословське питання ${ }^{4}$.

\footnotetext{
${ }^{1}$ Crisp, O. (ed.) (2014). Advancing Trinitarian theology: explorations in constructive dogmatics. Grand Rapids, Michigan: Zondervan, 171.

2 Manecke, D. (1972). Mission als Zeugendienst: Karl Barths theol. Wuppertal: Theologischer Verlag Brockhaus, 183-184.

${ }^{3}$ Бош, Д. (1997). Преобразование миссионерства, Библейская кафедра. Санкт-Петербург: Библия для всех, 427.

${ }^{4}$ Hartenstein, K. (1993). Die Mission als theologisches Problem: Beitrage zum grundsatzlichen Verstandnis der Mission. Berlin: Furche.
} 
Концепція Missio Dei вказує на те, що місія не $є$ переважно людським завданням, але вона $€$ в першу чергу ділом триєдиного Бога. Місія має фундаментом та відображає природу, волю і діяльність Бога. Місія церкви може бути правильно усвідомлена лише як участь у місії Бога. Леслі Ньюбігін пише: «Місія не $\epsilon$ нашою, але Божою» і додає- «ми запрошені брати участь у діяльності Бога, яка має визначальне значення для всього творіння» ${ }^{1}$. Ньюбігін закликає розробити експліцитну тринітарну концепцію для богослов'я місії у відповідь на «церквоцентричну» концепцію місії, яка була характерна для Міжнародної місіонерської конференції 1938 року в Тамбарані. Він вважає, що місіологія цієї конференції була «обгрунтована виключно на особі і ділі Христа, без належного врахування всієї тринітарної доктрини Бога» ${ }^{2}$. Він пропонує розвинуту тринітарну доктрину про Бога з метою помістити діло Христа і місію церкви у всеохоплюючий контекст провидіння Бога Отця над усім життям світу і суверенної свободи Духа, який є Господом церкви. Католицький богослов Стівен Беванс навіть заявляє: «Бог є місія. Не те що Бог має місію, але Бог $\epsilon$ місія» ${ }^{3}$. Бог у своїй глибинній сутті $\epsilon$ все-проникаючою любов'ю, яка творить, визволяє і зцілює творіння.

Джон Хофмаєр у короткій статті Місіональна Трійця зауважує, що задовго до використання терміну missio Dei і перш ніж слово «місія» увійшло у вжиток для описання життя і завдання церкви, термін місія використовувався у богословському дискурсі, а саме для означення тринітарних відносин ${ }^{4}$. Тома Аквінський (1225-1274) присвятив 43 питання Суми Теології темі «Про місію божественних Осіб»5. Тома говорить про дві тринітарні місії: місію/посилання Сину і місію/посилання Духа. Тринітарні місії описують те, як Син і Дух приходять у створений світ. Для Томи місії Сина і Духа відрізняються від внутрішньо тринітарної ідентичності як друга і третя Особи Трійці. Син народжується і Дух ісходить у вічності і тому походження Сина і Духа є вічними. Місії в свою чергу передбачають входження у просторово-часову реальність i тому є тимчасовими $\mathrm{i}$ темпоральними.

Триєдиний Бог як Отець, Син і Святий Дух є не статичним буттям поза людським буттям, який не турбується про людину i ніяк не відноситься до людини. Навпаки, Бог $є$ рухом i спілкуванням у Собі, Він сходить у створений світ щоб явити Свою славу і принести людям спасіння. Триєдиний Бог, який відкривається людям через Ісуса з Назарету і в силі Святого Духу може бути краще описаний при допомозі дієслова, а не іменника. Бог не є статичною «особистістю», Бог є особистістю-у-русі. Він завжди присутній у Своєму творінні і працює над його зціленням і спасінням. Він запрошує людей з маленької планети Земля до співпраці і партнерства з собою. Тома Аквінський говорив про Бога як про «першу сутність», яка «необхідно актуальною» і $є$ «чистим актом» ${ }^{6}$. Бонавентура (1221-1274) називав Бога «проникаючою добротою та любов’ю» ${ }^{7}$. Бог у Своій глибинній ідентичності є спілкуванням. Це тринітарне спілкування виливається на все творіння, зціляючи і освячуючи його і запрошуючи його до цього спілкування ${ }^{8}$.

Бог підносить людей до участі в Його благодаті і спільноті Його вічного життя. Ця участь завдячує своєму походженню і силі не є людським зусиллям, а діяльності Бога як Трійці. Бог є Богом місії. Бог є Богом, який відправляє на місію9. Посилання Сина і Духа Святого у створений світ $є$ найвищим вираженням божественної місіонерської активності. Реальна божественна таємниця місії полягаю у пришесті і втілені Сина, який посланий Отцем, є змістом цієї місії, і в свою чергу надихається Духом і посилає Духа. Хоча традиційно християнське богослов'я відрізняє божественні Особи і приписує кожній тринітарній Особі особливі дії (appropriationes) такі як Творець, Спаситель i Освячуючий, було б неправильно відокремлювати Отця, Сина і Святого Духа на основі їх діяльності в ікономії, тому що кожна божественна Особа задіяна в діях двох інших ${ }^{10}$. Неподільний

\footnotetext{
${ }^{1}$ Newbigin, L. (1964). Trinitarian faith and today's mission. Richmond: John Knox Press, 78.

2 Там само, 198-199.

${ }^{3}$ Bevans, S. (2009). The Mission has a Church: An Invitation to the Dance. Australian eJournal of Theology, 14 (1), 3.

${ }^{4}$ Hoffmeyer, J. F. (2001). The Missional Trinity. Dialog: A Journal of Theology 40 (2), 108.

${ }^{5}$ Аквинский, Ф. (2002). Сумма теологии, 1, 518.

6 Там само, 29.

${ }^{7}$ Delio, I. (1999). Bonaventure's Metaphysics of the Good, 60 (2), 232.

${ }^{8}$ Boff, L. (1993). Trinity, in Mysterium Liberationis: Fundamental Concepts Of Liberation Theology. N.Y: Orbis Books, 389.

${ }^{9}$ Thompson, J. (1994). Modern trinitarian perspectives. New York: Oxford University Press, 69.

10 Там само.
} 
Бог присутній своєю місією у кожній тринітарній Особі, хоча кожна Особа має свою унікальну і особливу місію, яка звершується в єдності з іншими Особами.

Це розуміння місії, основане на діяльності триєдиного Бога по відношенню людей містить у собі критику інших поглядів на основу місіонерської діяльності християнської церкви. В минулому богослов'я місії намагалося обгрунтувати необхідність місії посилаючись на Біблію, потребу людей, завдання церкви і завдання розповсюджувати християнську культуру і цивілізацію. Були також спроби аргументувати на користь місії усвідомленими чи неусвідомленими потребами нехристиян або суб'єктивними чи об' єктивними потребами християн передавати свою віру іншим ${ }^{1}$. Для руху євангельських християн також було характерним фундувати місію на гріховності людини. Харді і Форд критикували цей підхід, який базувався на проблемі гріха. Вони говорять, що проповідники змушують людей «відчувати гріх і нещастя, а також визнати себе винними i неадекватними, а потім пропонують їм Євангелію як відповідь» ${ }^{2}$. Вони ж вважають, що суттю місії та євангелізму є внутрішня цінність, краса та любов Бога, радість пізнання Бога і довіри Йому. Цей підхід узгоджується з трансформацією місіонерської діяльності багатьох християнських церков у 20-му столітті. Християнська місія починалася як місія Західної церкви, з часом вона стала місією світової церкви і в кінці місією Бога до церкви і світу.

У місії триєдиного Бога Він $є$ Тим, хто посилає, $є$ посланим i $є$ Тим, хто приходить. Враховуючи відмінність божественних Осіб, слід відрізняти також особливу місію кожної Особи, але у перспективі єдності триєдиного Бога. Бог не посилає на місію когось іншого як Його представника, як це вважає аріанство. Карл Барт говорить: «Бог діє і приходить як Господь у повноті своєї божественності, а також у формі великого смирення, пониження, страждання і служіння і в цей же час у величній силі і любові» ${ }^{3}$. В історії творіння не існувало моменту, коли Бог не був присутній у творінні. Стівен Беванс називає динаміку Божої присутності у твориві «буттям зсередини-назовні» ${ }^{4}$. Сповідуючи єдність божественної сутності і єдність дії божественних Осіб, ми розглянемо участь у місії Бога кожної Особи окремо.

Місія Бога як Творця. За Божим задумом створений всесвіт має бути сферою миру, свободи i справедливості. Всесвіт потрапив у полон людського гріха та зла, проте Бог обіцяє визволення. Підсумковий документ Лютеранської всесвітньої федерації, який був прийнятий на конференції в Аддіс Абаба в Ефіопії в 1988 році твердить: «Місія Бога Творця є детермінантою, основою і обіцянкою для всього творіння» ${ }^{5}$. Текст з послання до Римлян 8 розділ вказує на цю обіцянку Бога Творця: «Бо чекання створіння очікує 3'явлення синів Божих, бо створіння покорилось марноті не добровільно, але через того, хто скорив його, в надії, що й саме створіння визволиться від неволі тління на волю слави синів Божих. Бо знаємо, що все створіння разом зідхає й разом мучиться аж досі. Але не тільки воно, але й ми самі, маючи зачаток Духа, і ми самі в собі зідхаємо, очікуючи синівства, відкуплення нашого тіла» (Рим. 8:19-23). Ця обіцянка визволення від поневолення тлінню говорить про участь усього творива у славній свободі дітей Божих. Божа обіцянка включає не лише «нове творіння» для створених особистостей через навернення від гріха до Бога, але також новий космос, який здобуде змінений порядок природи. Щоб зберегти Своє творіння благодаттю і врятувати його від хаосу Отець посилає Свого Сина. П. Т. Форсіт пише: «Першим місіонером був Бог Отець, який відправив Свого Сина у подобі гріховної плоті. Це є печатка та основа місіїблагодать, незаслужена милість Бога, вічне серце і мета Отця, який дарував нам не лише пророка, але умилостивлення» ${ }^{6}$. Окремі богослові, як Барт і Ньюбегін вважають, що сотеріологічна діяльність Бога $є$ основою и смислом творіння. Ньюбегін говорить, що зосередженість проповіді Ісуса на проголошенні Царства Божого $є$ «справжнім секретом всесвітньої і космічної історії» ${ }^{7}$. Карл Барт

\footnotetext{
${ }^{1}$ Georg., F.(1958). Vicedom, Missio Dei: Einführung in eine Theologie der Mission. Munich: Ch. Kaiser, 12.

${ }^{2}$ Ford, H., Ford, D. (1984). Jubilate: Theology in Praise. London: Darton, Longman and Todd, 149.

${ }^{3}$ Bevans, S. (2009). The Mission has a Church: An Invitation to the Dance. Australian eJournal of Theology, 14 (1), 4.

4 Там само.

${ }^{5}$ Reinbold, W. (1989). Lutherischerweltbund - Dokumentation, Gottes Mission als Gemeinsame Aufgabe. Göttingen: Kreuz Verlag, 7.

${ }^{6}$ Taylor, P. (1908). Forsyth, Missions in state and church: sermons and addresses.(London: Hodder and Stoughton, 270 .

${ }^{7}$ Newbigin, L. (1995). The Open Secret: An Introduction to the Theology of Mission. Grand Rapids, Mich:

W.B. Eerdmans, 110.
} 
вбачає сенс творіння зосередженим в обрані і завіті, які є волею Бога Отця щоб за посередництвом Сина примирити космос з Собою ${ }^{1}$. Божа місія є всесвітньою і космічною у своєму всеохоплюючому масштабі. Якщо Отець є Творець, то Син є агентом творіння і зберігає весь космос уєдності, попереджуючи скочування творіння в хаос.

Місія Бога Сина. Бог Отець діє в особливий спосіб, посилаючи Сина як Слово, який не лише проголошує, але також і втілює Царство Боже у своєму житті і своїй особі. У цьому полягає Євангелія Його місії у світ. Син засвоює людську природу, приймаючи і переживаючи Божий гнів та суд за людські гріхи, і смертю і воскресінням перемагає гріх, смерть і всі сили темряви. Місія Сина примирення творіння з Творцем є унікальною і ексклюзивною, проте вона $\epsilon$ інклюзивною з своєю місіонерською перспективою. Вона $є$ центром і фокусом missio Dei. П. Т. Форсіт говорить: «Другим місіонером був Син, апостол нашого сповідання, справжній попередник апостолів... Він умалив себе у цій чужій країні «земля», упокорив себе до смерті, навіть до смерті на хресті» ${ }^{2}$. У документі Лютеранської всесвітньої федерації зазначається «Посилання Христа для спасіння світу є центром місії Бога улюдську історію, яка знаходиться у проміжку між творінням і його оновленням у славі» ${ }^{3}$. «Як настало ж виповнення часу, Бог послав Свого Сина» (Гал. 4:4), Боже Слово стало тілом, Божа присутність здобула людське обличчя. Бог стає присутнім у видимий, виразний i конкретний спосіб. Ісус був людиною, яка $є$ ведена і натхнена Божим Духом. Всі синоптичні Євангелії починають свою розповідь про служіння Христа з слів «Ісус був поведений Духом» (Мт. 4:1, Мк. 1:12, Лк. 4:1). Інавгураційна проповідь Христа в Назареті починається словами: «На Мені Дух Господній, бо Мене Він помазав... Послав Він ...» (Лк. 4:18). Робота Духа у пророка Ісаї стає завданням Ісуса - це Його програма служіння. Стівен Беванс говорить: «У цьому служінні Ісус відкриває Бога, який є дієсловом. Бог є Богом, який панує, прощає, оздоровлює, спасає, і несе примирення» ${ }^{4}$.

Уругвайський богослов визволення Хуан Луїс Сегундо пише «Бог схожий на Ісуса» ${ }^{5}$ Слід зауважити, що Сегундо не говорить, що Ісус подібний до Бога, як ніби люди вже знають, хто такий Бог. Сегундо хоче сказати що, саме Ісус показує нам, який є Бог. Коли ми бачимо те, як Ісус навчав, діяв і страждав, ми бачимо, як Бог навчає і діє, і страждає. Через три століття християнська церква зіткнулася саме з цим питанням у полеміці з Арієм. Якщо Ісус не був істинним Богом (homoousios з Отцем), то люди насправді не знали б який є Бог. Проте, ми знаємо який є Бог, тому що Ісус $є$ істинним Богом.

Місія Святого Духа. Місія Святого Духа є близько пов'язаною з місією Сина. Дух сходить на Ісуса і наділяє Його здібністю проповідувати, вчити, оздоровлювати і здійснювати чудеса i в такий спосіб здійснювати Своє месіанське покликання. Дух Святий надихає Сина перебувати в радості спілкування з Отцем, Він прославляє Сина і Отця і разом з Сином прославляє Отця. У деяких текстах Писання Дух майже ототожнюється з Сином, проте Дух є відмінний від Сина ${ }^{6}$. На відміну від Сина, який є об'єктивною реальністю одкровення, Дух є суб'єктивною реальністю одкровення і знаходиться на стороні віруючого ${ }^{7}$. Дух Святий є духом Христа, Він робить віруючих «новим творінням» у Христі. Дух створює спільноту віри і формує віруючих в образ Христа. Він дає людям дари і завдання і цим готує їх на служіння і місію. Дух є знаком і печаттю майбутнього спадку віруючих. Він об'єднує віруючих з Христом, що вказує на Його роль у Трійці- бути фактором єдності і спільності Отця і Сина.

Божою постійною місією $є$ Його діяльність у світі через Духа Святого. Стівен Беванс говорить: «3 першої наносекунди існування творіння Бог був там, у повноті Божественної таємниці, через присутність Святого Духу» ${ }^{8}$. Дух Святий $\epsilon$ Божим «буттям з середини-назовні». На перших сторінках Біблії Дух описаний як дихання, вітер, ruach Божий. Він ширяє над первісним хаосом як птах висиджує над своїм гніздом. Він є Духом, який вдихається в Адама, щоб зробити його «душею

\footnotetext{
${ }^{1}$ Barth, K. (1961). Church Dogmatics. T. \& T. Clark, IV,1, 22.

${ }^{2}$ Forsyth, P. T. (1908). Missions in state and church: sermons and addresses. London: Hodder \& Stoughton, $270-271$.

3 The Lutheran World Federation (2020). Homepage $<$ https://www.lutheranworld.org $>$ (2020, травень, 08).

${ }^{4}$ Bevans, S. (2009). The Mission has a Church: An Invitation to the Dance. Australian eJournal of Theology, 14 (1), 6.

${ }^{5}$ Segundo, J. L. (1987). Christ in the Spiritual Exercises of St. Ignatius. Maryknoll, N.Y: Orbis Books, 22.

${ }^{6}$ Thompson, J. (1994). Modern trinitarian perspectives. N.Y.: Oxford University Press, 71.

${ }^{7}$ Barth, K. (1961). Church Dogmatics. T. \& T. Clark, IV, 2, 322.

${ }^{8}$ Bevans, S. (2009). The Mission has a Church: An Invitation to the Dance. Australian eJournal of Theology, 14 (1), 4.
} 
живою». Дух Святий надихав пророків, перебував з Ісусом з початку і до кінця Його місії на землі, Він посилає і споряджає церкву на виконання місії. Дух Святий посилає і надихає на виконання місії людей усіх історичних епох. Форсіт пише: «Третім місіонером є Святий Дух, якого Спаситель посилає на всю землю, який приходить і в силі та ніжності впорядковує весь всесвіт і підпорядковує всі народи Царству Христа» ${ }^{1}$

Дух Святий здійснює місію разом з Отцем і Сином у творінні і спасінні, у приході і житті Христа. Дух є посланим і приходить до людей. Він $є$ так само як Христос заступником і захисником перед Богом Отцем (Рим. 8).

Отець, Син і Дух Святий постійно взаємодіють у кожній дії, перебуваючи відмінними Особами. Діяльність тринітарних Осіб є спільною по відношенню до створених істот і фактично $є$ одним ділом. Діяльність Трійці об’єднана спільністю цілі, волі і єдиної божої сутності. Ця ідея виражається принципом - opera trinitatis ad extra indivisa (діяльність Трійці поза нею $€$ неподільною) $)^{2}$. Цей принцип не веде до поглинання відмінностей єдністю Трійці і він не нівелює відмінностей божественних Осіб, а скоріше вказує на участь кожної божественної Особи в діяльності двох інших Осіб.

Місія церкви. Концепція missio Dei розглядає місію, в першу чергу, як діяльність триєдиного Бога, проте це не означає, що людина не допускається до участі у цій діяльності. Попередня критика концепції місії як завдання церкви чи людей була спрямована не на вилучення церкви чи людської передачі Свангелії взагалі. Метою цієї критики було показати залежність місії церкви від місії триєдиного Бога. Під Божим правлінням все знаходить своє місце і свій порядок. Missio Dei не означає, що Бог робить усе, а люди не можуть і не роблять нічого. У світлі missio Dei триєдиного Бога як основи і агента місії люди покликані та споряджені Богом стати живим знаряддям в Божій особливій місії і стати її учасником.

На початку 21-го століття ідея тринітарної місії вже знайшла богословське обгрунтування і навіть з'явилося декілька поглядів на місію церкви в тринітарному контексті. Дєвід Фітч і Гофрей Холскло виділяють три концепції тринітарно-орієнтованої місії: погляд на місію, орієнтований на Духа, погляд на місію, орієнтований на Ісуса, погляд на місію, орієнтований на втілення³

Погляд на місію, орієнтований на Духа розглядає місію як всеохоплюючу діяльність Бога по визволенню і встановленню миру у світі через послання Духа Отцем і Сином. Посланий Богом Отцем Син проголошує прихід Царства Божого, здійснює його інавгурацію і посилає Своїх апостолів у світ з проповіддю про реальність Царства. Центральною подією тут є доручення Христа Своїм учням: «Мир вам! Як Отець послав Мене, і Я вас посилаю! Сказавши оце, Він дихнув, і говорить до них: Прийміть Духа Святого!» (Ів. 20:21,22). Це текст показує роль церкви у тринітарній місії. Отець посилає Сина, Отець і Син посилає Духа, і Син посилає церкву у силі Духа. Дєвід Фітч і Гофрей Холскло вважають, що місіонерський рух післявоєнної Європи розумів себе в термінах послання Божого Духу у світ для здійснення Божої місії, в якій церква покликана брати участь ${ }^{4}$. Missio Dei не є завданням окремої церкви або народу. Церква не повинна вважати, що вона має місію, скоріше, церква $\epsilon$ покликаною брати участь в місії Бога у світ, яка вже-у-процесі. Рання монографія Юргена Мольтмана Церква в силі Святого Духу (1993) також є вкладом в тринітарний погляд на місію, орієнтований на Духа. Він зображає місію триєдиного Бога у світі як створення Духом нового майбутнього, і церква має долучитися до цієї роботи Духа

Погляд на місію, орієнтований на Ісуса визначається головним чином «посиланням Сина». Прихильники цього погляду вважають, що єдність діяльності Трійці має бути збережена, проте, слід усвідомлювати, що місія повинна завжди мати «христологічне ядро», тому що Отець і Дух не можуть бути пізнаними без Сина. Дух Святий походить від Отця і Сина, проте, Він посилається 3 метою актуалізувати в теперішньому сотеріологічні результати уже здійсненого Ісусом Христом спасіння. Особа, діло і вчення Ісуса, відкрите у Писані через Духа Святого для окремої людини $€$

\footnotetext{
${ }^{1}$ Forsyth, P. T. (1908). Missions in state and church: sermons and addresses. London: Hodder \& Stoughton, $270-271$.

2 Thompson, J. (1994). Modern trinitarian perspectives. N.Y.: Oxford University Press, 72.

${ }^{3}$ Fitch, D. E., Holsclaw, G. (2013). Mission amid Empire: Relating Trinity, Mission, and Political Formation. Missiology: An International Review, 41 (4), 390. DOI: https://doi.org/10.1177/0091829613480626.

4 Там само.

${ }^{5}$ Moltmann, J. (1993). The Church in the Power of the Spirit: A Contribution to Messianic Ecclesiology. Minneapolis: Fortress Press.
} 
основою для Божої діяльності у світі. Таким чином, христологія визначає місіологію, а місіологія, в свою чергу, визначає еклезіологію ${ }^{1 .}$

Дєвід Фітч і Гофрей Холскло вважають, що обидва погляди на місію, орієнтований на Духа та орієнтований на Ісуса $є$ недостатньо політично ангажованими і тому пропонують третій погляд, орієнтований на втілення². На нашу думку два попередніх погляди є недостатньо тринітарними $\mathrm{i}$ страждають однобоким акцентом на одній Особі Трійці. Для погляду на місію, орієнтованого на втілення, характерне розуміння тринітарної місії Бога через історичне спасіння Бога здійснене через життя, смерть, воскресіння і прославлення Христа. Проте, на відміну від погляду, орієнтованого на Ісуса, третій погляд вважає, що втілення Бога у Христі не було одноразовою подією - прихід і вихід зі світу. Скоріше боговтілення продовжується в посиланні Духа Отцем і Сином, як продовженні присутності Христа уцеркві- тілі Христа. Церква $є$ соціальним продовженням кенотичного боговтілення у світі, і виражає кенотичне існування ${ }^{3}$. Після вознесіння Христа, боговтілення не просто повернулося до Отця. Скоріше, боговтілення розширилося і тепер включає два елементи: (1) космічне панування Христа над усім світом, і (2) тіло Христа, церкву. Юрген Мольтман називає це продовження боговтілення Christus prolongatus i наголошує, що церква $\epsilon$ тілом Христа в повному розумінні цього слова. Девід Фітч говорить: «Церква як соціальне тіло Христа живе у світі і в контексті діл Бога. Вона є продовженням втілення Христа посланого Отцем 3 метою долучитися до того, що Він уже здійснює через Духа. Церква є невідривною частиною тринітарної місії, яка вже триває» ${ }^{4}$.

У документі Лютеранської всесвітньої федерації заявляється: «Місія церкви бере свій початок від місії самого Бога» ${ }^{5}$. Джон Томпсон вважає, що одним із способів виразити цю ідею може бути проведення аналогії між роллю та місцем людської природи Христа в божественній ікономії́. Так само як людина Ісус $є$ причетним до життя Бога завдяки єдності з Сином, християни також введені в спілкування з Сином силою Святого Духу і стають причетними до сенсу, сили, праведності і миру сотеріологічного діла Христа. Джордж Вісдом говорить: «Місія - це не лише слухняність слову Господа, це не лише обов'язок церковної спільноти, місія - це участь у апостольстві Сина, missio Dei - це всеосяжне завдання по встановленню панування Христа над усім визволенним творінням» ${ }^{7}$ В подібний спосіб висловлюється і документ Лютеранської всесвітньої федерації: «Основне завдання церкви полягає в участі у місії Бога. Місія церкви бере свій початок від місії самого Бога i основується на Божому само-одкровенні» ${ }^{8}$. Участь церкви в місії Бога не полягає в повторені чи імітації Божої діяльності у світі, завдання церкви полягає в тому щоб словом і ділом проголошувати присутність і пришестя Царства Божого і виголошувати послання Бога про спасіння в Ісусі Христі. Місія має подвійний імпульс: Царство Боже і його справедливість і вістка про спасіння у Христі. Царство Боже вказує на справедливі відносини у суспільстві, вість спасіння через Христа закликає встановити правильні відносити з Богом та один зодним в християнській спільноті. Було б неправильно протиставляти ці два завдання як це часто траплялося у минулому. Царство і вість про спасіння є невід'ємними частинами missio Dei та Його церкви до світу.

Якщо церква належить Богові, $є$ тілом Христа і храмом Святого Духу, то місія $є$ притаманною самій природі церкви. Новозавітні метафори для церкви - тіло Христа, народ Божий, наречена Христа - не описують статичну групу, а скоріше, живу спільноту, яка діє у світі і для світу. Карл Барт підкреслював, що всі служіння в церкві, всі види діяльності церкви, навіть ті, які спрямовані на збудування спільноти повинні мати спрямованість на досягнення людей світу поза церквою9 .

\footnotetext{
${ }^{1}$ Hirsch, A. (2006). The forgotten ways: reactivating the missional church. Grand Rapids, Mich: Brazos Press, $142-144$.

${ }^{2}$ Fitch, D. E., Holsclaw, G. (2013). Mission amid Empire: Relating Trinity, Mission, and Political Formation.

Missiology: An International Review, 41 (4), 396. DOI: https://doi.org/10.1177/0091829613480626.

${ }^{3}$ Yoder, J. H., Hauerwas, S. (2011). The Priestly Kingdom: Social Ethics as Gospel, 145. Ebookcentral

$<$ https://ebookcentral.proquest.com/lib/exeter/detail.action?docID=4699918>. (2020, березень, 08).

${ }^{4}$ Fitch, D. E. (2011). The end of evangelicalism? discerning a new faithfulness for mission: towards an evangelical political theology. Eugene, Or: Cascade Books, 170.

${ }^{5}$ The Lutheran World Federation (2020). Homepage <https://www.lutheranworld.org> (2020, травень, 08).

${ }^{6}$ Thompson, J. (1994). Modern trinitarian perspectives. N.Y.: Oxford University Press, 73.

${ }^{7}$ Vicedom, G. F. (1975). Missio Dei: Einführung in eine Theologie der Mission. München: Kaiser, 12.

${ }^{8}$ The Lutheran World Federation (2020). Homepage $<$ https://www.lutheranworld.org $>$ (2020, травень, 08).

${ }^{9}$ Barth, K. (1961). Church Dogmatics. T. \& T. Clark, IV, 2, 322.
} 
Уся церква та кожен іï член покликані брати участь у місії. До місії церкви також належить пошук єдності церкви, яка з одного боку є даром Божим, я 3 другого боку є завданням віруючих реалізовувати єдність церкви в історичному просторі ${ }^{1}$.

Місія церкви безпосередньо пов'язана з сотеріологічним ділом Христа і місією Святого Духа. Місія церкви полягає в продовжені справи Христа по примиренню, яке має інклюзивний характер і охоплює все людство та увесь всесвіт. Діло примирення $є$ ексклюзивним ділом Христа в єдності з Отцем і Святим Духом, проте воно є всеохоплюючим по своєму масштабу. Ще одним важливим фактором місії церкви $є$ те, що вона здійснюється в силі Святого Духу. Автор Дії Апостолів говорить: «Та ви приймете силу, як Дух Святий злине на вас, і Моїми ви свідками будете в Срусалимі, і в усій Юдеї та в Самарії, та аж до останнього краю землі». (Дії 1:8). Дух Святий надихає церкву на свідчення не лише для всіх народів та етносів, але також робить це на протязі усієї історії до іï завершення у есхатоні. Таким чином, місія церкви має пневматологічне і есхатологічне вимірювання які базуються на природі та місії триєдиного Бога. П. Т. Форсіт влучно підсумовує: «Четвертим місіонером $є$ церква і ці чотири місіонери (Отець, Син, Дух і Церква) всі залученні до одного божественного спасіння, якому ми завдячуємо»².

Висновки. В останні десятиліття тринітарного богослов'я також проникає у сферу місіології. Тринітарна концепція Missio Dei вказує на те, що місія не є лише завданням для церкви, але вона $€$ в першу чергу ділом триєдиного Бога. Місія має основу в Трійці та відображає природу, волю і діяльність Отця, Сина і Духа. У місії триєдиного Бога Бог є Тим, хто посилає, є посланим і $є$ Тим, хто приходить. Місіологічний наголос на missio Dei закликає до того, щоб об'єднувати місіологію і тринітарне богослов'я в єдиний богословський дискурс.

Бог є Богом місії. Початковою основою місії триєдиного Бога є Бог Отець, який створив світ і посилає Сина у силі Святого Духа для спасіння світу. Безпосередньою основою місії Бога $€$ спасіння, здійснене Сином через своє життя, смерть і воскресіння. І найближчою основою місії Трійці є Дух Святий, який діє у віруючих. Місія базується на волі, історії і діяльності благодаті і любові триєдиного Бога Отця, Сина і Святого Духа.

Розуміння місії як діла Отця, Сина і Святого Духу допомагає будь якому руху за ріст церкви уникнути поверховості і надто великого наголосу на людських методах здійснення місіонерської роботи. Тринітарне розуміння місії дає можливість християнину бути відкритим до діалогу, проповідувати і вчитися, давати і приймати, задавати питання і слухати відповіді.

\section{References:}

1. Alekseyeva, O. (1989). Konets monopolizmu [The end to monopoly]. Komsomolskaya pravda. Sobesednik [Komsomol truth. Interlocutor], 41 (294). [in Russian].

2. Akvinskiy, F. (2002). Summa teologii [Sum of theology], 1. [in Russian].

3. Barth, K. (1961). Church Dogmatics. T. \& T. Clark, IV, 2. [in English].

4. Bevans, S. (2009). The Mission has a Church: An Invitation to the Dance. Australian eJournal of Theology, 14 (1), 3-6. [in English].

5. Boff, L. (1993). Trinity, in Mysterium Liberationis: Fundamental Concepts Of Liberation Theology. N.Y: Orbis Books. [in English].

6. Bosh, D. (1997). Preobrazovaniye missionerstva, Bibleyskaya kafedra [Transformation of Missionary Work]. Bible Chair]. St. Petersburg: The Bible for All. [in Russian].

7. Crisp, O. (ed.) (2014). Advancing Trinitarian theology: explorations in constructive dogmatics. Grand Rapids, Michigan: Zondervan. [in English].

8. Delio, I. (1999). Bonaventure's Metaphysics of the Good, 60 (2), 232-235. [in English].

9. Fitch, D. E. (2011). The end of evangelicalism? discerning a new faithfulness for mission: towards an evangelical political theology. Eugene, Or: Cascade Books. [in English].

10. Fitch, D. E., Holsclaw, G. (2013). Mission amid Empire: Relating Trinity, Mission, and Political Formation. Missiology: An International Review, 41 (4), 390-396. DOI: https://doi.org/10.1177/0091829613480626. [in English].

11. Ford, H., Ford, D. (1984). Jubilate: Theology in Praise. London: Darton, Longman and Todd. [in English].

12. Forsyth, P. T. (1908). Missions in state and church: sermons and addresses. London: Hodder \& Stoughton, 270-271. [in English].

\footnotetext{
${ }^{1}$ The Lutheran World Federation (2020). Homepage $<$ https://www.lutheranworld.org $>$ (2020, травень, 08).

${ }^{2}$ Forsyth, P. T. (1908). Missions in state and church: sermons and addresses. London: Hodder \& Stoughton, 271.
} 
13. Georg., F.(1958). Vicedom, Missio Dei: Einführung in eine Theologie der Mission. Munich: Ch. Kaiser. [in English].

14. Hartenstein, K. (1993). Die Mission als theologisches Problem: Beitrage zum grundsatzlichen Verstandnis der Mission. Berlin: Furche. [in English].

15. Hirsch, A. (2006). The forgotten ways: reactivating the missional church. Grand Rapids, Mich: Brazos Press, $142-144$. [in English].

16. Hoffmeyer, J. F. (2001). The Missional Trinity. Dialog: A Journal of Theology 40 (2). [in English].

17. Manecke, D. (1972). Mission als Zeugendienst: Karl Barths theol. Wuppertal: Theologischer Verlag Brockhaus, 183-184. [in English].

18. Moltmann, J. (1993). The Church in the Power of the Spirit: A Contribution to Messianic Ecclesiology. Minneapolis: Fortress Press. [in English].

19. Newbigin, L. (1964). Trinitarian faith and today's mission. Richmond: John Knox Press. [in English].

20. Newbigin, L. (1995). The Open Secret: An Introduction to the Theology of Mission. Grand Rapids, Mich: W.B. Eerdmans. [in English].

21. Reinbold, W. (1989). Lutherischerweltbund - Dokumentation, Gottes Mission als Gemeinsame Aufgabe. Göttingen: Kreuz Verlag. [in English].

22. Segundo, J. L. (1987). Christ in the Spiritual Exercises of St. Ignatius. Maryknoll, N.Y: Orbis Books. [in English].

23. Taylor, P. (1908). Forsyth, Missions in state and church: sermons and addresses.(London: Hodder and Stoughton. [in English].

24. The Lutheran World Federation (2020). Homepage <https://www.lutheranworld.org> (2020, May, 08). [in English].

25. Thompson, J. (1994). Modern trinitarian perspectives. N.Y.: Oxford University Press. [in English].

26. Vicedom, G. F. (1975). Missio Dei: Einführung in eine Theologie der Mission. München: Kaiser. [in English].

27. Yoder, J. H., Hauerwas, S. (2011). The Priestly Kingdom: Social Ethics as Gospel, 145. Ebookcentral $<$ https://ebookcentral.proquest.com/lib/exeter/detail.action?docID=4699918>. (2020, May, 08). [in English]. 